\title{
TNF- $\alpha$ and IL-8 as Prognostic Markers of Birth Outcome in Overweight and Non-overweight Pregnant Women
}

\author{
Karlina Elksne*, Antra Jurka*, Dace Rezeberga**, Peteris Tretjakovs* \\ *Riga Stradins University, Latvia \\ $* *$ Riga Maternity hospital, Latvia
}

\begin{abstract}
Summary
Introduction. Overweight has become a major risk factor for various diseases. Compared with normal weight overweight pregnant women have an increased risk of various complications in childbirth - invasive fetal monitoring, perineal ruptures, operative vaginal deliveries, cesarean sections, increased gestational age at delivery, and increased maternal length of stay are present. Both pregnancy and childbirth is a conditions significantly affected by the the immune system. However, this relationship and the possibility of its practical use is still not fully explored.

Aim of the study. Our aim is to determine whether overweight have the same impact on obstetrical outcome as obesity, explore changes of Interleukin-8 (IL-8) and Tumor Necrosis Factor-alpha (TNF-a) levels in the first and second trimester of pregnancy, compare these changes in normal weight pregnant women and pregnant women with overweight, to clarify their relationship to pregnancy outcome and to determine whether these cytokines have the potential to serve as biomarkers for prediction of labor complications.

Material and methods. This was a prospective, longitudinal study were we enrolled 55 pregnant women in their first antenatal visit. Blood samples were taken at different weeks of pregnancy. TNF-a and IL-8 concentrations were measured by Luminex XMAP technology (Luminex Corporation). Statistical analysis was performed using LibreOffice Calc, the Fisher exact test, Ttest, Spearman's rank correlation coefficient and a non-parametric Mann-Whitney-Wilcoxon test. For all statistical analyses, $p<0.05$ was considered statistically significant.

Results. Labor dysfunction and cesarean section were more frequently observed in women with high BMI. In cases of vaginal delivery ruptures were more often for patients in high BMI group but the difference is small. Although average birth weight was slightly lower in normal BMI group, the difference is not statistically significant $(p=0.13)$. Male gender babies were more often for women with high BMI, but statistical difference is not significant $(p=0.15)$. Comparing the levels of TNF- $a$ and IL-8 in different weeks of pregnancy no statistically significant difference between the study groups was found. There was no strong tendencies in dynamics in TNF-a and IL-8 levels in differend first and second trimester weeks of pregnancy.

No statistically significant differences in levels of TNF- $a$ and IL-8 depending on the fetal macrosomia were observed, but IL-8 level correlated with labour dysfunction and mode of delivery.

Conclusions. Overweight is a risk factor for labor dysfunction and probability of CS. TNF-a and IL-8 levels in early pregnancy does not differ in women with and without elevated BMI. In first and second trimesters of pregnancy no dynamics in TNF-a and IL-8 levels in maternal serum is observed. IL-8 level in the second trimester is correlated with labour dysfunction and increased cesarean section risk. This is an important finding, but its clinical value still requires further research.
\end{abstract}

Key words: maternal overweight; cytokines; TNF-a; IL-8; labor outcome.

\section{INTRODUCTION}

Overweight has become a major risk factor for various diseases. And concern is the fact that the number of people with elevated Body Mass Index (BMI) continues to grow. Obstetricians are increasingly confronted with elevated BMI patients and maternal obesity significantly contributes to a poorer prognosis for mother and baby during delivery and in the immediate post-partum period (22). Compared with normal weight overweight pregnant women have an increased risk of various complications in childbirth - invasive fetal monitoring, perineal ruptures, operative vaginal deliveries, caesarean sections (CS), increased gestational age at delivery, and increased maternal length of stay are present $(5,6)$.
It has been found that pregnancy is a condition of moderate inflammation, although the physiological role of this low-grade inflammation remains unclear and also, obesity is a condition of chronic inflammation. This contributes to increased levels of circulating proinflammatory cytokines (21). There is evidence that the immune system is also important for the development of labor. Cytokines themselves might mediate the leukocyte attraction that occurs at the time of parturition. They might mediate leukocytic infiltration, either directly or via upregulation of cell adhesion molecules (26).

Tumor Necrosis Factor-alpha (TNF- $\alpha$ ) is an inflammatory cytokine primary produced by macrophages and belongs 
to the subpopulation of Thl lymphocytes. In pregnancy it is also produced by placenta and membranes (4). This cytokine regulates a number of cell functions, including cell proliferation, differentiation, apoptosis and is involved in the metabolic regulation of glucose, lipids, and insulin resistance $(18,4)$. Studies have confirmed that increase of TNF- $\alpha$, is related to the risk for developing obstetric complications, particularly recurrent fetal loss, GDM, hypertensive syndromes, and fetal growth restriction, but these results remain controversial (2). And there are limited data on the early pregnancy.

Interleukin-8 (IL-8) is a member of CXC chemokine subfamily it is responsible for the recruitment of monocytes and neutrophils thus engaging in inflammatory response (1). In terms of pregnancy the relationship has been found that risk of spontaneous preterm delivery and preeclampsia is increased in women with high IL-8 levels $(20,3,23)$. However, there is no conclusive data on the early pregnancy cytokine levels and birth outcome.

\section{AIM OF THE STUDY}

We wanted to determine whether excess weight have an impact on obstetrical outcome.

Objective of this study is to explore IL- 8 and TNF- $\alpha$ level changes in the first and second trimester of pregnancy, compare these changes in normal weight pregnant women and pregnant women with overweight and to clarify their relationship to pregnancy outcome. The aim is to determine whether these cytokines have the potential to serve as biomarkers for prediction of labor complications.

\section{MATERIAL AND METHODS}

This was a prospective longitudinal study in which we included women who received perinatal care at Riga Maternity Hospital Outpatient Department and gave birth at Riga Maternity Hospital in years 2011th and 2012th. Pregnant women were recruited at their first antenatal visit at 9-12 weeks of pregnancy. The study included healthy, adult pregnant women without history of previous adverse obstetrical outcome and CS. Exclusion criteria were serious illnesses - cardiovascular, respiratory, endocrine abnormalities, allergies and smoking.

All the women recruited were measured for weight and height, and the BMI was calculated. Two groups of patients were defined according to the result: one group with excessive weight (defined as BMI above $24.9 \mathrm{~kg}$ / $\mathrm{m}^{2}$ ) and a second group with normal BMI

55 women were enrolled, 17 in group with excess weight (average BMI $28.81 \mathrm{~kg} / \mathrm{m}^{2}$ - 11 overweight(BMI from 24.9-29.9 $\mathrm{kg} / \mathrm{m}^{2}$ ) and 6 obese (BMI from $30 \mathrm{~kg} /$ $\left.\mathrm{m}^{2}\right)$ ) and 38 in group with normal BMI (average BMI $\left.21.69 \mathrm{~kg} / \mathrm{m}^{2}\right)$.

Further for women from both groups blood samples were taken in their first visit and in visits at 15-18 and 24-28 weeks gestation.
Following delivery main clinical characteristics were collected and included to the analyses: mode of delivery, indication for CS(labor dysfunction, fetal distress, cephalopelvic disproportion, placental pathologies), complications of vaginal delivery (labor dysfunction, fetal distress, ruptures during childbirth- any degree cervical, vaginal or perineal lesions which were diagnosed and required suturing ), gestational age at delivery, birth weight and gender.

The study was approved by the Latvian University Ethics Committee. A written informed consent was obtained from each patient.

Blood samples were collected from an antecubital vein after a 12-h fast.

The samples were allowed to coagulate for 20 to $30 \mathrm{~min}$ at room temperature. Sera were separated by centrifugation at $4{ }^{\circ} \mathrm{C}$ for $20 \mathrm{~min}$ at $1600 \times \mathrm{g}$. All specimens were immediately aliquoted, frozen, and stored at $-80^{\circ}$. TNF- $\alpha$ and IL- 8 concentrations were measured by Luminex xMAP technology (Luminex Corporation).

Statistical analysis was performed using LibreOffice Calc. Data are reported as percentages for categorical variables and as median for continuous variables. The Fisher exact test was used to compare categorical variables and Ttest to compare continuous variables between groups. Spearman's rank correlation coefficient (Spearman's rho) was applied to assess relationship between cytokines and BMI. A non-parametric MannWhitney-Wilcoxon test was used for evaluation between TNF- $\alpha$ and IL- 8 levels and fetal macrosomia and obstetrical outcome. For all statistical analyses, $\mathrm{p}<0.05$ was considered statistically significant.

\section{RESULTS}

Differences were found in the outcome of pregnancy in women with and without excess weight.

Obstetrical outcome of the study population are shown in Table 1.

Table 1. Obstetrical outcome characteristics of the study groups

\begin{tabular}{|l|l|l|l|}
\hline & $\begin{array}{l}\text { High BMI } \\
(\mathrm{n}=17)\end{array}$ & $\begin{array}{l}\text { Normal BMI } \\
(\mathrm{n}=38)\end{array}$ & P-value \\
\hline $\begin{array}{l}\text { Age (mean } \\
\text { number) }\end{array}$ & $\begin{array}{l}29.94 \\
(21-40)\end{array}$ & $\begin{array}{l}28.89(19- \\
38)\end{array}$ & 0.49 \\
\hline $\begin{array}{l}\text { Gravidity (mean } \\
\text { number) }\end{array}$ & $2.11(1-5)$ & $2.26(1-5)$ & 0.68 \\
\hline $\begin{array}{l}\text { Parity (mean } \\
\text { number) }\end{array}$ & $1.71(1-4)$ & $1.84(1-4)$ & 0.6 \\
\hline $\begin{array}{l}\text { Gestational age } \\
\text { (weeks) }\end{array}$ & $\begin{array}{l}39.59 \\
(37-41)\end{array}$ & $\begin{array}{l}39.53(38- \\
41)\end{array}$ & 0.83 \\
\hline $\begin{array}{l}\text { Caesarean } \\
\text { Section, \% (n) }\end{array}$ & $\begin{array}{l}47(8) \\
8(3)\end{array}$ & 0.002 \\
\hline $\begin{array}{l}\text { Labour } \\
\text { dysfunction, } \\
\%(n)\end{array}$ & $\begin{array}{l}43(6 \text { of } \\
14)\end{array}$ & $8(3$ of 36) & 0.01 \\
\hline
\end{tabular}




\begin{tabular}{|l|l|l|l|}
\hline & $\begin{array}{l}\text { High BMI } \\
(\mathrm{n}=17)\end{array}$ & $\begin{array}{l}\text { Normal BMI } \\
(\mathrm{n}=38)\end{array}$ & P-value \\
\hline $\begin{array}{l}\text { Ruptures in } \\
\text { childbirth, \% }(\mathrm{n})\end{array}$ & $\begin{array}{l}57(8 \text { of } \\
14)\end{array}$ & $50(15$ of 30) & 0.75 \\
\hline Birth weight $(\mathrm{g})$ & $\begin{array}{l}3954 \\
(3360- \\
4320)\end{array}$ & $\begin{array}{l}3754(2730- \\
5130)\end{array}$ & 0.13 \\
\hline $\begin{array}{l}\text { Male gender, \% } \\
(\mathrm{n})\end{array}$ & $65(11)$ & $42(16)$ & 0.15 \\
\hline
\end{tabular}

No significant difference in terms of age, gravidity, parity and gestational age among study groups were found. But large differences were observed in the mode of delivery. Cesarean section ( due to various reasons dysfunction, fetal distress, cephalopelvic disproportion or placental pathologies) were more frequently applied to women with high BMI $(47 \%$ vs $8 \% ; \mathrm{p}=0.002)$. Labor dysfunction had $43 \%$ women of high BMI group and $8 \%$ women of normal BMI group $(p=0.01)$. In cases of vaginal delivery ruptures were more often for patients in high BMI group but the difference is small $(\mathrm{p}=0.75)$. Although average birth weight was $3954 \mathrm{~g}$ in high BMI group and $3754 \mathrm{~g}$ in normal BMI group, the difference is not statistically significant $(p=0.13)$. Male gender babies were more often for women with high BMI, but statistical difference is not significant $(65 \%$ vs. $42 \%$; $\mathrm{p}=0.15)$.

To exclude the possibility that birth complications in the group with excessive weight is more due to obese women, we compared data about adverse obstetrical outcome inside the group - between overweight and adipose women. The results, which we obtained showed that the percentage of complications was similar in both subgroups. Level of statistical significance of any of the parameter was not $\mathrm{p}<0.05$. Most notable difference was found in terms of risk of rupture in labor - $36.36 \%$ vs. $66.67 \%$, however, because of a small number of patients in each subgroup, this correlation can not be considered statistically significant $(\mathrm{p}=0.33)$.

Serum levels $(\mathrm{pg} / \mathrm{ml})$ of cytokines in pregnant women with high and normal BMI at different weeks of gestation are shown in Table 2 .

Table 2. Cytokine levels in pregnant women with high and normal BMI

\begin{tabular}{|l|l|l|l|l|}
\hline & $\begin{array}{l}\text { High } \\
\text { BMI }\end{array}$ & $\begin{array}{l}\text { Normal } \\
\text { BMI }\end{array}$ & $\begin{array}{l}\text { Spearman's } \\
\text { rho }\end{array}$ & P-value \\
\hline $\begin{array}{l}\text { TNF- } \alpha \text { at } \\
\text { 9-12 weeks } \\
\text { of gestation } \\
(\mathrm{pg} / \mathrm{ml})\end{array}$ & 8.4 & 8.2 & 0.076 & 0,65 \\
\hline $\begin{array}{l}\text { TNF- } \alpha \text { at } 15- \\
\text { l8 weeks of } \\
\text { gestation }(\mathrm{pg} / \\
\text { ml) }\end{array}$ & 8.1 & 9.4 & -0.051 & 0.76 \\
\hline
\end{tabular}

\begin{tabular}{|l|l|l|l|l|}
\hline $\begin{array}{l}\text { TNF- } \alpha \text { at } 24- \\
28 \text { weeks of } \\
\text { gestation }(\mathrm{pg} / \\
\mathrm{ml})\end{array}$ & 9.0 & 8.5 & $-0,001$ & 1.00 \\
\hline $\begin{array}{l}\text { IL-8 at 9-12 } \\
\text { weeks of } \\
\text { gestation }(\mathrm{pg} / \\
\mathrm{ml})\end{array}$ & 27.2 & 28.9 & 0.049 & 0.79 \\
\hline $\begin{array}{l}\text { IL-8 at } 15- \\
18 \text { weeks of } \\
\text { gestation }(\mathrm{pg} / \\
\text { ml) }\end{array}$ & 22.7 & 55.5 & 0.225 & 0.25 \\
\hline $\begin{array}{l}\text { IL-8 at 24- } \\
28 \text { weeks of } \\
\text { gestation }(\mathrm{pg} / \\
\text { ml) }\end{array}$ & 26.5 & 19.8 & 0.001 & 1.00 \\
\hline
\end{tabular}

Comparing the levels of TNF- $\alpha$ and IL- 8 in different weeks of pregnancy no statistically significant difference between the study groups of overweight and pregnant women with normal BMI was found.

Dynamic of TNF- $\alpha$ and IL- 8 values in first and second trimester of pregnancy is displayed in Figures 1-6.

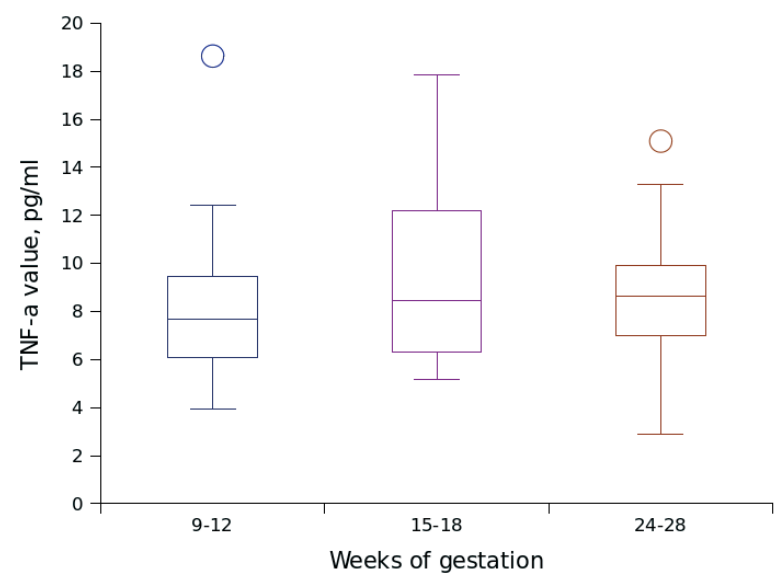

Fig. 1: TNF- $\alpha$ values of normal BMI patients

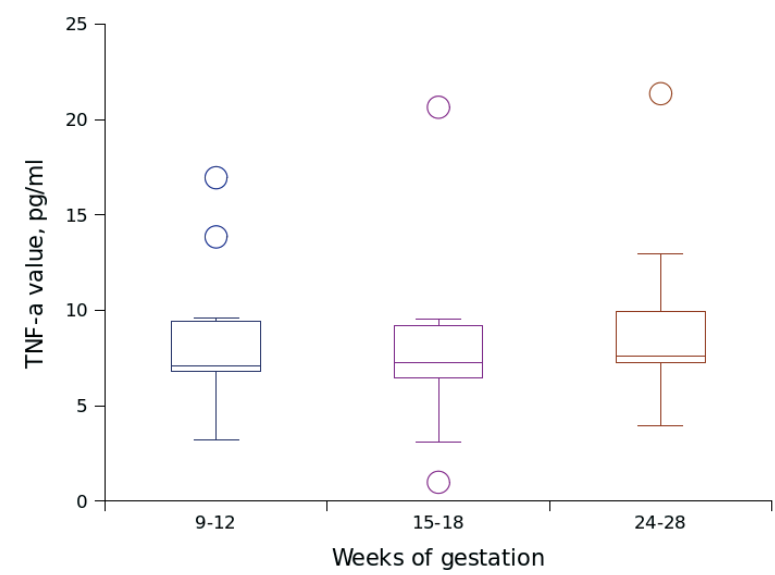

Fig. 2: TNF- $\alpha$ values of high BMI patients 


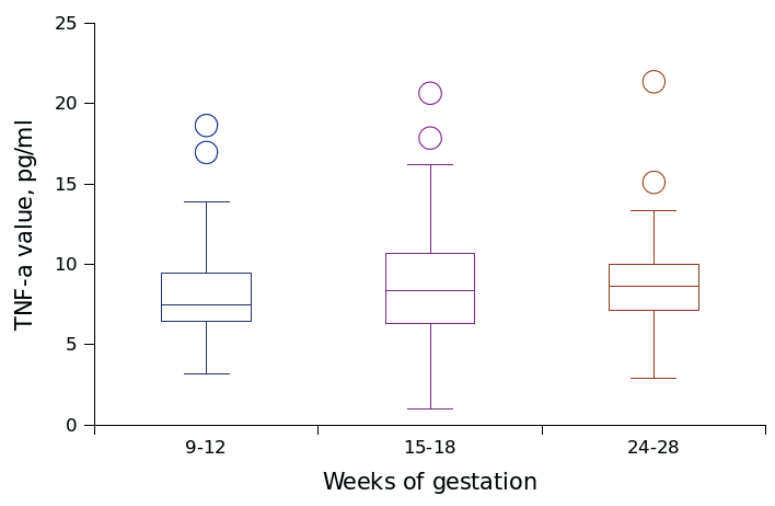

Fig. 3: TNF- $\alpha$ values of all patients

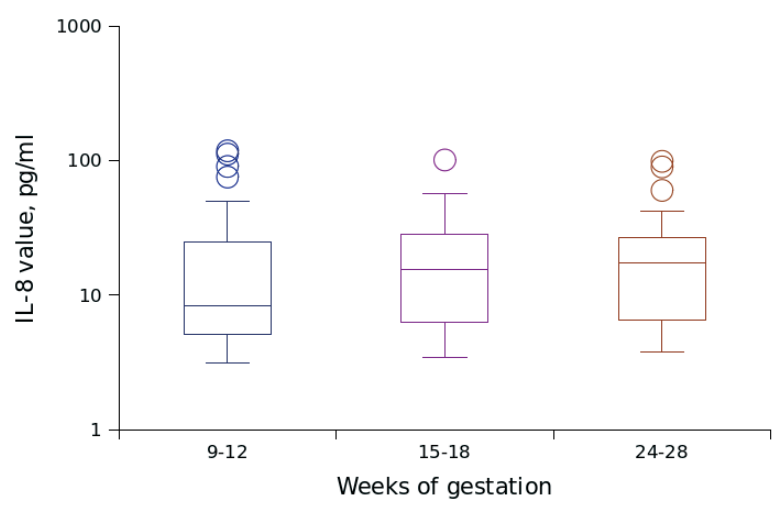

Fig. 4 IL-8 values of normal BMI patients

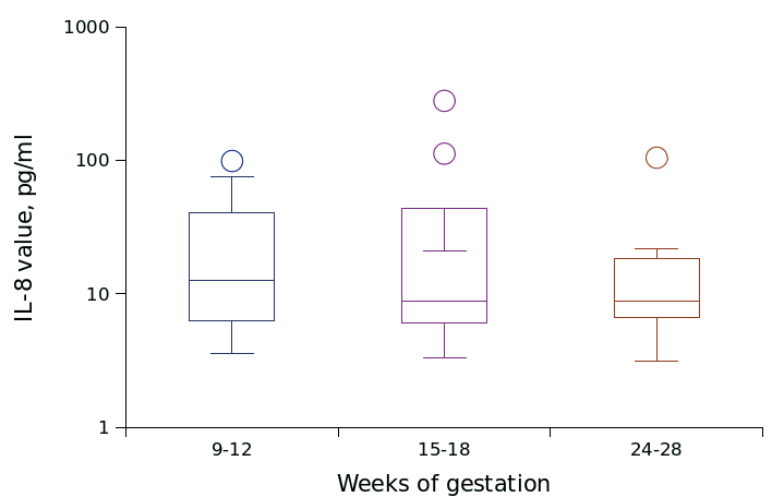

Fig. 5 IL-8 values of high BMI patients

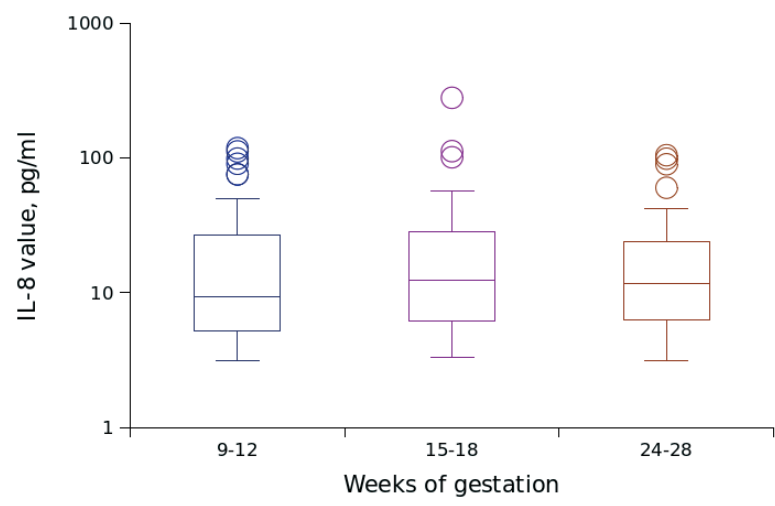

Fig. 6 IL-8 values of all patients

There were no strong tendencies in dynamics in TNF- $\alpha$ and IL-8 levels in different first and second trimester weeks of pregnancy.

No statistically significant differences in levels of TNF- $\alpha$ and IL- 8 depending on the fetal macrosomia were observed, but IL-8 level correlated with labor dysfunction and mode of delivery. Statistical reliability is shown in Table3.

Table 3. The statistical significance of the relationship between cytokine levels and labor outcomes- results of Wilcoxon test

\begin{tabular}{|c|c|c|c|c|c|c|}
\hline & $\begin{array}{l}\text { TNF- } \\
\text { alpha } \\
\text { at 9-12 } \\
\text { weeks } \\
\text { of ges- } \\
\text { tation }\end{array}$ & $\begin{array}{l}\text { TNF- } \\
\text { alpha at } \\
15-18 \\
\text { weeks } \\
\text { of ges- } \\
\text { tation }\end{array}$ & $\begin{array}{l}\text { TNF- } \\
\text { alpha at } \\
24-28 \\
\text { weeks of } \\
\text { ges-tation }\end{array}$ & $\begin{array}{l}\text { IL- } 8 \text { at } \\
9-12 \\
\text { weeks } \\
\text { of ges- } \\
\text { tation }\end{array}$ & $\begin{array}{l}\text { IL- } 8 \text { at } \\
15-18 \\
\text { weeks } \\
\text { of ges- } \\
\text { tation }\end{array}$ & $\begin{array}{l}\text { IL-8 at } \\
24-28 \\
\text { weeks } \\
\text { of ges- } \\
\text { tation }\end{array}$ \\
\hline $\begin{array}{l}\text { Fetal } \\
\text { macro- } \\
\text { somia }\end{array}$ & $\begin{array}{l}\mathrm{W}= \\
134.5 \\
\mathrm{p} \text {-value = } \\
1\end{array}$ & $\begin{array}{l}\mathrm{W}=158, \\
\mathrm{p} \text {-value }= \\
0.5618\end{array}$ & $\begin{array}{l}\mathrm{W}=133.5 \\
\mathrm{p} \text {-value }= \\
0.4398\end{array}$ & $\begin{array}{l}\mathrm{W}=79, \\
\mathrm{p} \text {-value }= \\
0.6201\end{array}$ & $\begin{array}{l}\mathrm{W}=93, \\
\mathrm{p} \text {-value }= \\
0.5327\end{array}$ & $\begin{array}{l}\mathrm{W}=78 \\
\mathrm{p} \text {-value } \\
=0.5295\end{array}$ \\
\hline $\begin{array}{l}\text { Labor } \\
\text { dysfun- } \\
\text { ction }\end{array}$ & $\begin{array}{l}\mathrm{W}=64, \\
\mathrm{p} \text {-value }= \\
0.957\end{array}$ & $\begin{array}{l}\mathrm{W}=96 \\
\mathrm{p} \text {-value }= \\
0.01899\end{array}$ & $\begin{array}{l}W=52, \\
p \text {-value }= \\
0.3881\end{array}$ & $\begin{array}{l}W=64, \\
p \text {-value }= \\
0.957\end{array}$ & $\begin{array}{l}\mathrm{W}=96 \\
\mathrm{p} \text {-value }= \\
0.01899\end{array}$ & $\begin{array}{l}\mathrm{W}=52, \\
\mathrm{p} \text {-value } \\
=0.3881\end{array}$ \\
\hline $\begin{array}{l}\text { Mode } \\
\text { of deli- } \\
\text { very }\end{array}$ & $\begin{array}{l}\mathrm{W}= \\
143.5, \\
\mathrm{p} \text {-value = } \\
0.5087\end{array}$ & $\begin{array}{l}\mathrm{W}=50, \\
\mathrm{p} \text {-value }= \\
0.9138\end{array}$ & $\begin{array}{l}=74, \\
p \text {-value }= \\
0.07043\end{array}$ & $\begin{array}{l}W=68, \\
p \text {-value }= \\
0.1897\end{array}$ & $\begin{array}{l}\mathrm{W}=42, \\
\mathrm{p} \text {-value }= \\
0.7796\end{array}$ & $\begin{array}{l}\mathrm{W}=98 \\
\mathrm{p} \text {-value } \\
= \\
0.03875\end{array}$ \\
\hline
\end{tabular}

\section{DISCUSSION}

In this study, we wanted determine whether there is the possibility to find biomarkers that could help to predict obstetric complications in early pregnancy. We chose two cytokines from different groups in order to to test their level in maternal serum and to find out whether there are differences depending on the BMI and on obstetric outcome.

Most studies have analyzed pregnant women with obesity but to situation in Latvia much greater importance would be if specified role of excessive weight in the development of obstetric complications would be 
established. Therefore, in this study we chose to split patients with and without high BMI. And our study confirmed that increased weight itself is a risk factor for birth dysfunction and higher rate of CS. Similar results were also obtained in other studies, but in those obesity was analyzed as a risk factor $(6,24)$. A large retrospective cohort study demonstrated that elevated prepregnancy weight increase the risk of prolonged and postterm delivery (41 or 42 weeks) (10). In our prospective study we did not find a significant difference at the pregnancy solution time. Mothers who are obese have an increased risk of tears during childbirth (16). In our study that was not confirmed, but it can be explained by the fact that CS outweigh the vaginal birth for women with a high BMI. Studies in which fetal weight is compared between pregnant women with and without obesity show that it is significantly larger in cases of obesity (25). In our research we found slightly higher fetal weight in women with higher BMI, but the difference was not statistically significant. This suggests that the excessive weight do not affect the child's risk of macrosomia.

In terms of cytokine level changes during pregnancy our study showed no significant changes in TNF-alpha and IL-8 levels in maternal serum. Other longitudinal studies have found an increase of TNF-alpha in late (34-36 weeks) pregnancy (15). This is explained by the fact that the placenta were shown to express TNF and its receptors is with greatest activity evident in third trimester which explains the increase in TNF- $\alpha$ levels (9). Also IL-8 levels did not change in pregnancy, they rose just in labour (11).

We found no correlation between TNF- $\alpha$ and maternal BMI. Our findings are similar to results of study were women had their inflammatory markers measured at term before labour (17).

In another study correlation has been found between IL-8 and maternal adiposity, but samples were taken and cytokines were measured only at 28 and 37 weeks gestation so there is no clarity on the situation in early pregnancy (8). According to results of our research IL-8 levels during early pregnancy does not depend on prepregnancy BMI.

Also we found that maternal TNF- $\alpha$ and IL-8 levels in first and second trimester do not have relationship with fetal macrosomia. Similar results were also obtained in researches were IL- 8 and TNF- $\alpha$ levels were analyzed in cord blood samples and in maternal blood samples taken in second half of pregnancy $(18,8)$. TNF- $\alpha$ also did not correlated with labor dysfunction and CS risk. This is consistent with the results which are obtained in study were material from 55 patients were taken with blood sampling from a clamped segment of cord after delivery of the fetus and from the cord at its insertion into the placenta after delivery of the placenta. TNF- $\alpha$ levels for both patient groups were uniformly low for all of the cord measurements with no significant differences noted (7).

There are few studies to look for correlations between cytokine levels in early pregnancy and mode of delivery. So far, IL-8 role as a biomarker the most have been studied in relation to risk of premature birth $(12,13)$. Our results show that IL-8 levels in the second trimester is correlated with birth dysfunction and thus the risk of cesarean sections. This is a very important discovery, which still requires further research. However, this could be due to the valuable role played by immune system in childbirth. Also we know that IL-8 increases activity of collagenase and metalloproteinases 8 and 9, which are required for softening of cervical tissue what is very important during childbirth (14). These factors could be decisive in the development of complications in labor and thus affect the need for SC. Our study shows that there are changes that exist in a relatively early time of pregnancy. Of course, larger studies with greater sub-groups in order to clarify the prognostic role of cytokine in the development of complications in labor is necessary.

\section{CONCLUSIONS}

1. Not only obesity, but also excessive weight altogether is a risk factor for labor dysfunction and probability of CS.

2. TNF- $\alpha$ and IL-8 levels in early pregnancy does not differ in women with and without elevated BMI.

3. In first and second trimesters of pregnancy no dynamics in TNF- $\alpha$ and IL-8 levels in maternal serum is observed.

4. IL-8 level in the second trimester is correlated with labour dysfunction and increased cesarean section risk. This is an important finding, but its clinical value still requires further research.

\section{Conflict of interest: None}

\section{REFERENCES}

1. Apostolakis S, Vogiatzi K, Amanatidou V, Spandidos DA. Interleukin 8 and cardiovascular disease // Cardiovasc Res, 2009; 84:353 - 60.

2. Brogin Moreli J, Cirino Ruocco AM, Vernini JM, Rudge MV, Calderon IM. Interleukin 10 and tumor necrosis factor-alpha in pregnancy: aspects of interest in clinical obstetrics // ISRN Obstet Gynecol, 2012; 2012:230742.

3. Cemgil Arikan D, Aral M, Coskun A, Ozer A. Plasma IL-4, IL-8, IL-12, interferon- $\gamma$ and CRP levels in pregnant women with preeclampsia, and their relation with severity of disease and fetal birth weight // J Matern Fetal Neonatal Med, 2012; 25:1569- 73 .

4. Coughlan MT, Oliva K, Georgiou HM, Permezel JMH, Rice GE. Glucose-induced release of tumour necrosis factor-alpha from human placental and adipose tissues in gestational diabetes mellitus // Diabetic Medicine, 2001; 18:921 - 927.

5. Cunningham CE, Teale GR. A profile of body mass index in a large rural Victorian obstetric cohort // Med J Aust, 2013; 198:39 - 42.

6. Dennedy MC, Dunne F. The maternal and fetal impacts of obesity and gestational diabetes on pregnancy outcome // Eur J Endocrinol, 2010; $162: 213-20$. 
7. Duncombe G, Veldhuizen RA, Gratton RJ, Han VK, Richardson BS. IL-6 and TNFalpha across the umbilical circulation in term pregnancies: relationship with labour events // Early Hum Dev, 2010;86:113 - 7 .

8. Farah N, Hogan AE, O'Connor N, Kennelly MM, O'Shea D, Turner MJ. Correlation between maternal inflammatory markers and fetomaternal adiposity // Cytokine, 2012; 60:96 - 9.

9. Haider S, Knöfler M. Human tumour necrosis factor: physiological and pathological roles in placenta and endometrium // Placenta, 2009; 30:111 - 23.

10. Halloran DR, Cheng YW, Wall TC, Macones GA, Caughey AB. Effect of maternal weight on postterm delivery // J Perinatol, 2012; 32:85 - 90.

11. Hebisch G, Neumaier-Wagner PM, Huch R, von Mandach U. Maternal serum interleukin-1 beta, -6 and -8 levels and potential determinants in pregnancy and peripartum // J Perinat Med, 2004; $32: 475-80$.

12. Hee L. Likelihood ratios for the prediction of preterm delivery with biomarkers // Acta Obstet Gynecol Scand, 2011; 90:1189 - 99.

13. Holst RM, Mattsby-Baltzer I, Wennerholm UB, Hagberg $\mathrm{H}$, Jacobsson B. Interleukin-6 and interleukin-8 in cervical fluid in a population of Swedish women in preterm labor: relationship to microbial invasion of the amniotic fluid, intraamniotic inflammation, and preterm delivery // Acta Obstet Gynecol Scand, 2005; 84:551 - 7.

14. Houben ML, Nikkels PG, van Bleek GM, Visser GH, Rovers MM, Kessel H, de Waal WJ, Schuijff L, Evers A, Kimpen JL, Bont L. The association between intrauterine inflammation and spontaneous vaginal delivery at term: a cross-sectional study // PLoS One, 2009; 4:e6572.

15. Kirwan JP, Hauguel-De Mouzon S, Lepercq J, Challier JC, Huston-Presley L, Friedman JE, Kalhan SC, Catalano PM. TNF-alpha is a predictor of insulin resistance in human pregnancy // Diabetes, 2002; 51:2207 - 13 .

16. Liu X, Du J, Wang G, Chen Z, Wang W, Xi Q. Effect of pre-pregnancy body mass index on adverse pregnancy outcome in north of China // Arch Gynecol Obstet, 2011; 283:65 - 70.

17. Madan JC, Davis JM, Craig WY, Collins M, Allan W, Quinn R, Dammann O. Maternal obesity and markers of inflammation in pregnancy // Cytokine, 2009; 47:61 - 4 .
18. Mestan K, Ouyang F, Matoba N, Pearson C, Ortiz $\mathrm{K}$, Wang X. Maternal obesity, diabetes mellitus and cord blood biomarkers in large-for-gestational age infants // J Pediatr Biochem, 2010; 1:217 - 224.

19. Patial S, Parameswaran N. Tumor necrosis factor- $\alpha$ signaling in macrophages // Critical Reviews in Eukaryotic Gene Expression, 2010; 20:87 - 103.

20. Rode L, Klein K, Larsen H, Holmskov A, Andreasen KR, Uldbjerg N, Ramb J, Bødker B, Skibsted L, Sperling L, Hinterberger S, Krebs L, Zingenberg H, Weiss EC, Strobl I, Laursen L, Christensen JT, Skogstrand K, Hougaard DM, Krampl-Bettelheim E, Rosthøj S, Vogel I, Tabor A. Cytokines and the risk of preterm delivery in twin pregnancies // Obstet Gynecol, 2012; 120:60 - 8.

21. Rode L, Nilas L, Wøjdemann K, Tabor A. Obesityrelated complications in Danish single cephalic term pregnancies // Obstet Gynecol, 2005; 105:537 -42 .

22. Simpson H, Ells LJ, Rankin J, Wilkinson J, Lang R, Brown TJ, Summerbell CD. The impact of maternal BMI status on pregnancy outcomes with immediate short-term obstetric resource implications: a metaanalysis // Obesity Reviews, 2008; 9:635 - 83.

23. Tosun M, Celik H, Avci B, Yavuz E, Alper T, Malatyalioğlu E. Maternal and umbilical serum levels of interleukin-6, interleukin-8, and tumor necrosis factor-alpha in normal pregnancies and in pregnancies complicated by preeclampsia // J Matern Fetal Neonatal Med, 2010; 23:880 - 6.

24. Verdiales M, Pacheco C, Cohen WR. The effect of maternal obesity on the course of labor // J Perinat Med, 2009; 37:651 - 5.

25. Vinayagam D, Chandraharan E. The adverse impact of maternal obesity on intrapartum and perinatal outcomes // ISRN Obstet Gynecol, 2012; 2012:939762.

26. Young A, Thomson AJ, Ledingham M, Jordan F, Greer IA, Norman JE. Immunolocalization of proinflammatory cytokines in myometrium, cervix, and fetal membranes during human parturition at term // Biol Reprod, 2002; 66:445 - 9.

\section{Address:}

Karlina Elksne

Matīsa 50-14, LV-1009,

Riga, Latvia

karlina.elksne@inbox.lv 